\title{
Towards the Sustainability Enhancement: Identification of Impediments on Integrated Reporting
}

\author{
Nawarathna Liyanage Erandi Abeywardana ${ }^{1,2, *}$, S.M. Ferdous Azam ${ }^{1}$, Kevin Low Lock Teng. ${ }^{1}$ \\ ${ }^{1}$ Postgraduate Centre (PGC), Management and Science University (MSU), Malaysia \\ ${ }^{2}$ Department of Commerce \& Financial Management, University of Kelaniya, Sri Lanka
}

Received December 12, 2021; Revised February 7, 2022; Accepted February 22, 2022

\section{Cite This Paper in the following Citation Styles}

(a): [1] Nawarathna Liyanage Erandi Abeywardana, S.M. Ferdous Azam, Kevin Low Lock Teng., "Towards the Sustainability Enhancement: Identification of Impediments on Integrated Reporting," Universal Journal of Accounting and Finance, Vol. 10, No. 2, pp. 591 - 600, 2022. DOI: 10.13189/ujaf.2022.100224.

(b): Nawarathna Liyanage Erandi Abeywardana, S.M. Ferdous Azam, Kevin Low Lock Teng. (2022). Towards the Sustainability Enhancement: Identification of Impediments on Integrated Reporting. Universal Journal of Accounting and Finance, 10(2), 591 - 600. DOI: 10.13189/ujaf.2022.100224.

Copyright $\bigcirc 2022$ by authors, all rights reserved. Authors agree that this article remains permanently open access under the terms of the Creative Commons Attribution License 4.0 International License

\begin{abstract}
Integrated Reporting is an emerging corporate reporting model amongst the other voluntary corporate reporting practices. However, the impediments may hinder the adoption of integrated reporting practices, and it may be affected by organizational sustainability. Hence, this study aims to examine impediments that affect the adoption of integrated reporting practice and the impact of the adoption or non-adoption of integrated reporting on organizational sustainability. The study adopted a qualitative research approach. Based on the judgmental sampling method, the data was collected through 15 semi-structured interviews from the responsible officers of integrated reporting in public listed companies in Sri Lanka. Data from interviews was analysed using the directed content analysis. The results showed that impediments to integrated reporting practice have occurred through the international integrated reporting framework, external factors, and organizational factors. Furthermore, IR practices' adoption reinforces the identification of sustainability issues and strengthens the integration of sustainability issues into strategies. These findings contribute to the literature on impediments of integrated reporting and organizational sustainability in the context of developing countries. These findings could be helpful to professional accounting bodies, regulatory bodies, and firms that need to mitigate the impediments to integrated reporting and enhance organizational sustainability. This paper adds to the limited available literature on the impediments of integrated reporting for the emerging economy. Moreover, this study is the first to reveal the
\end{abstract}

impact of adoption/non-adoption of integrated reporting practices on organizational sustainability.

Keywords Impediments, Integrated Reporting, Public Listed Companies, Sustainability

\section{Introduction}

Firms tend to practice integrated reporting (IR) in response to the investors' and other stakeholders' growing expectations on accountability and transparency. Hence, organizations produce integrated reports with the primary purpose of explaining their value creation, preservation, and erosion over time. Thus, IR can be identified as a powerful tool for sustainability, showing how organizations create sustainable value. Furthermore, the organizations can achieve sustainable development goals through the value creation process [1]. According to the IIRC [2] application of IR gives various advantages such as disclosing the information which is aligned with the requirements of the investors [3], higher the level of trust with stakeholders [4], better resource allocation decisions [4,5], enriching risk management [4,6], greater the engagement with stakeholders $[4,6]$, lower reputation risk $[4,7]$, and orient on future [4]. Hence, Business $20^{1}[8]$ and

\footnotetext{
${ }^{1}$ Business 20 consist with the business leaders from large companies and they try to influence the governments (Argentina, Australia, Brazil, Canada, China, France, Germany, India, Indonesia, Italy, Japan, Mexico, Russia, Saudi Arabia, South Africa, South Korea, Turkey, United
} 
the European Commission emphasized the importance, and the need of IR in the international context and Chartered Accountants of Sri Lanka [9] and Securities Exchange Commission of Sri Lanka [10] also highlighted the importance and direction towards the IR in the Sri Lankan context.

Even though the professional accounting bodies, regulatory bodies, and academicians emphasize the importance of adopting IR, only $34 \%$ of PLCs are applying the International Integrated Reporting Framework (IIRF) and published integrated annual reports in Sri Lanka. Hence, the Sri Lankan companies are still lethargic in adopting IR [11], and IR practice is still growing [12] in Sri Lanka. This may be due to the impediments that hinder IR practice and international studies [13,14], and some Sri Lankan studies [15-18] discuss the impediments of IR. Indeed, a handful of studies have begun to study the impediments behind the IR, but further discussions are needed, and it is still questionable what the actual barriers are. Hence, there is little evidence of the studies which are focused on impediments to IR. Furthermore, if the organizations do not adopt IR due to the impediments, this will impact the organization's sustainability. Hence, it is needed to emphasize the impact of IR adoption/ non-adoption on organizational sustainability.

One reason for the limited diffusion of IR may be related to the lack of sufficient empirical evidence indicating the actual concreteness of the barriers for organizations that decide to pursue integrated reporting and lack of emphasis on the importance of the adoption of IR practices on organizational sustainability. Therefore, this study aims to identify the impediments to IR practices of public listed companies in Sri Lanka and explore the impact of IR adoption/ non-adoption on organizational sustainability.

Hence, this study contributes to the current literature by focusing on the impediments of IR and the impact of IR adoption/ non-adoption on organizational sustainability in a developing country. The identification of impediments can be used as the first step in minimizing the effect of such impediments in IR adoption and enhancing sustainability practices. Hence, this study puts forward ideas for impediments of integrated reporting to evolve to continue pace with the developing economy and address the issues of wider relative parties by focusing on organizational sustainability.

The remainder of this article is structured as follows. The next section provides the literature review with the focus of IR with its impediments and relationship among IR and organizational sustainability. The following section presents the methodology. The succeeding section shows the study findings with the discussion. The paper ends with the conclusion, implication, recommendation, and future research directions.

Kingdom, and the United States) of the G20.

\section{Literature Review}

This section explores the insights of empirical studies by providing foreground background to the study, including integrated reporting (IR), impediments to IR, and the impact of IR on organizational sustainability.

\subsection{Integrated Reporting}

Organizations have begun to disclose more financial, non-financial information, corporate social responsibility, and sustainability information since the early 2000 s by using various corporate reporting models. Compared to the other corporate reporting practices, sustainability reporting (SR) can be considered as a new corporate reporting phenomenon. It identified that organizations' environmental, social, and governance (ESG) issues as critical and needed to communicate that information to the stakeholders. Hence, the companies tend to disclose information on ESG matters through sustainability reports due to the pressures from the outside parties who expect to know about the non-financial issues of the companies [19]. Global Reporting Initiatives (GRI) guidelines established to enhance the quality, utility, and rigor of sustainability issues provided a framework for SR. Hence, it plays a vital role in the evolution of SR as the most crucial standard setter of SR. However, there is uncertainty about whether this sustainable information will be used in management decisions. Hence, a new avenue of corporate reporting is called, and consequently, (IR) came into practice. Therefore, SR is the predecessor of IR initiatives [20], and the integrated report is the evolution of sustainability report [21].

Moreover, disclosure of integrated information towards sustainability was to become a trend, and this trend was partly driven by the international integrated reporting framework (IIRF), which was introduced by the international integrated reporting council (IIRC) in 2013, a voluntary reporting tool that guides to report six capitals, content elements and the value creation story in a single report. The IIRC was established to intend the global focus of IR and promote IR in 2010 by the GRI and the Prince of Wales's Accounting for Sustainability Project as the sustainability reporting organizations. The IIRF's latest version is introduced in 2021, which discussed more on fundamental concepts: value creation and six capitals (financial, manufactured, intellectual, human, social and relationship and, natural), seven guiding principles: strategic focus and future orientation, connectivity of information, stakeholder relationships, materiality, conciseness, reliability, and completeness consistency, and comparability, and eight content elements: organizational overview and external environment, governance, business model, risks and opportunities, strategy and resource allocation, performance, outlook, and basis of preparation.

IR is firstly defined by the IIRC [2] in their publication of Towards integrated reporting, communicating value in 
the 21st Century. Secondly, IIRC [22] defined IR in their first publication of IIRF. Now, the latest definition of IR is stated in the current version of IIRF, which was issued in 2021. It defined IR as "a process founded on integrated thinking that results in a periodic integrated report by an organization about value creation, preservation or erosion over time and related communications regarding aspects of value creation, preservation or erosion" [23, p.54].

\subsection{Impediments on Integrated Reporting Practice}

Despite IR's significant benefits, the implementation of IR practice remains challenging, and barriers to companies' early adoption and implementation of effective IR practice remain. Based on the literature, it is possible to group the impediments into three categories: technical, external, and organizational.

IIRF's growing reputation is reflected in its prevalent adoption among more than 70 countries. However, scholars have identified the potential negative consequences of IIRF, which impede the adoption of IR practice. The complexity of the IIRF is one of the major challenges to enhance the IR practice [24-26], the complexity of capital measurements [18,27,28], determining the materiality of information [4], difficulty in defining report scope and content [4,29], difficulty in determining suitable content for strategic focus, strategic objectives, key performance indicators and forward-looking statements [4]. Furthermore, the balancing of organization story in the integrated annual report to satisfy the needs and expectations of stakeholders also identified as the challenge by Lodhia, [26]. Furthermore, combining the financial and non-financial information $[18,24,30]$ is also recognized as the impediments to IR.

Even though the supportive external environment is essential to the effective adoption of organizational practices, organizations cannot control external factors. Those factors may create opportunities and challenges to the organizational practices. Hence, the challenges of implementing IR or the slow adoption of IR may be due to external factors. Those factors are less demand from stakeholders [13], no mandatory requirement to the adoption [13,31], size of the stock market [13], lack of guidelines, frameworks, and reporting standards [4]. As per the IIRF guidelines, organizations should embed capital into strategies. However, it is a complicated process.

In addition to that, the challenges to adopting IR also occur in the organization itself. Effective implementation of executive IR practice requires unique and up-to-date internal processes as well as infrastructure transformation. Those causes are lack of experienced employees [13,18,25], employees resistance to change to IR [18,25], inadequate top management support $[18,25,28]$, lack of proper information systems and communications $[4,18,25]$, the difficulty of breaking silos [25,32], lack of understanding of the potentials of IR [29], time consume and costly [18], and lack of awareness and knowledge on IR $[13,15]$.

\subsection{Integrated Reporting and Organizational Sustainability}

Sustainability is the process of internalizing the social and environmental vectors within the organization's operations and implementing corporate strategies tailored to the stakeholders' interests [33]. Organizational sustainability becomes an important strategy for enhancing corporate capabilities to provide social and environmental benefits, in addition to providing economic benefits. Companies have faced sustainable problems over the past few decades, and public awareness has focused heavily on the role of firms. To reflect the transparency and accountability organizations tend to disclose more financial and non - financial information to their investors and other stakeholders. [34-38]. As a result, voluntary reporting practices, environmental reporting, triple bottom line reporting, corporate social responsibility reporting (CSR), and sustainability reporting (SR) come into practice.

Although social and environmental dimensions are common elements of CSR and SR, from 2000 to 2010, sustainability and corporate social responsibility merged to achieve the social and environmental character and stakeholder-oriented common goals. In SR, other than the social and environmental dimensions, the economic pillar is also included. GRI was created by Boston-based non-profit Ceres and the Tellus Institute in 1997 as a framework for sustainability reporting.

However, scholars pay attention to the drawbacks of SR. SR has a limited and fragmented nature, SR is historical, and it does not explore its key risks and future performance. Furthermore, the demands for accountability increased, and the organizations face the challenge of satisfying this accountability by using stand-alone SR [39]. Moreover, studies such as Lodhia, [26] questioned whether SR could improve sustainability in the world. Hence, there should be a new avenue of corporate reporting to face the SR's overcomes and satisfy the accountability. These arguments note that IR is a central single reporting tool that provides a complete picture of the company and its value creation process compared to financial and sustainability reporting.

Hence, IR can be considered as the one step further to the SR, and it is the extension to SR [36,40,41], and adoption of IR is facilitated by the already established SR mechanism of the firms [17]. Furthermore, Al-Htaybat \& von Alberti-Alhtaybat, [20] mentioned SR as a predecessor of IR initiatives, and the integrated report is the evolution of sustainability report [21]. Moreover, IR reflects the way that the sustainability issues of the organization are integrated with the organization's management and strategies [42].

Senior management plays a vital role in organizational sustainability. Adoption IR will reinforce the old 
management focus and awareness of the organization's long-term sustainability [43]. Hence, when the senior management pays more attention to environmental, social, and sustainability governance, it will lead to increased ability to manage the sustainability issues and their daily operations, ultimately affecting the IR process [44]. Furthermore, institutional investors believed that integrated reports better understand organizational sustainability [45].

\section{Methodology}

The study is an exploratory study that takes the qualitative approach. The study used a qualitative approach because researchers will not be able to identify the operational issues and impediments of IR implementation by using the quantitative analysis [46]. Hence, in-depth qualitative analysis is recommended [46,47].

The interview protocol was designed based on the reviewed literature and discussion with two officers involved with IR practice. The qualitative data were collected through the 15 semi-structured interviews. The interviewees were selected from the PLCs engaging with the IR practices based on the judgmental sampling technique. The selection of interviews was based on the consent of the Interviewer at the discretion of the Interviewer, ensuring that all information is covered by the knowledge and interviews [48]. Table 1 summarizes the profile of interviewees with their reference codes.

The interviews lasted from 35 minutes to 85 minutes. All the interviews are virtually based, audio or video recorded and transcribed. Identified themes in the literature are used to code the transcripts. To illustrate the key points, quotes were selected that best explained a particular situation.

\section{Findings and Discussion}

This section presents the study's findings with the insights of prior empirical studies. The findings and discussion show the impediments to IR and how the adoption/non-adoption of IR affects organizational sustainability.

\subsection{Impediments for Integrated Reporting}

Each interviewee mentioned different reasons as impediments to IR practice. In understanding the rationale behind the factors which are the main impediments to the adoption of IR in PLC in Sri Lanka, those factors can be divided into three main themes as technical factors, external factors, and organizational factors.

Table 1. Sample profile of the interviewees

\begin{tabular}{|c|c|c|c|c|}
\hline & $\begin{array}{c}\text { Interviewee } \\
\text { code }\end{array}$ & Industry & Interviewees' position & Experience \\
\hline 1 & IN 1 & Motor & Accountant & 15 years \\
\hline 2 & IN 2 & Construction and Engineering & Assistant Manager - Integrated reporting and & 10 years \\
\hline 3 & IN 3 & Banking and Finance & Chief Financial Officer & 6 years \\
\hline 4 & IN 4 & Manufacturing & Senior Manager, Corporate Strategy & 13 years \\
\hline 5 & IN 5 & Banking and Finance & Finance Manager & 11 years \\
\hline 6 & IN 6 & Manufacturing & Finance Manager & 20 years \\
\hline 7 & IN 7 & Manufacturing & Manager - Finance & 6 years \\
\hline 8 & IN 8 & Banking and Finance & Chief Financial Officer & 12 years \\
\hline 9 & IN 9 & Diversified Holdings & Finance Manager & 9 years \\
\hline 10 & IN 10 & Manufacturing & Accountant & 6 years \\
\hline 11 & IN 11 & Beverage, Foods, and Tobacco & Assistant Manager Finance & 8 years \\
\hline 12 & IN 12 & Diversified & Manager Finance & 13 years \\
\hline 13 & IN 13 & Banking and Finance & Senior Accountant & 7 years \\
\hline 14 & IN 14 & Healthcare & Chief Financial Officer & \\
\hline 15 & IN 15 & Hotels and Travels & &
\end{tabular}




\subsubsection{Technical Factors}

The IIRF has a complex scope in nature due to its principles-based requirements. Therefore, some of the interviewees arose the challenges that they faced through the IIRF, and these challenges were also identified by the scholars such as Steyen[4], Jayasiri[18], Iacuzzi, et.al.,[25], Lodhia[26], Robertson \& Samy[28], Maroun \& Mcnally[29], PwC[30], Lakshan, et al. [49]. In line with those findings, some interviewees also mentioned the complexity of finding required information as per IIRF $[18,24,25,26,30]$. As per interviewee IN 2, "The required information for the report is not always available". Hence, the organizations should pay additional effort to collect the required information. Moreover, the complexity of the IR process was highlighted by IN3 and according to him, "Implementation of IR can be complex and challenging in terms of calculating non-financial data to combine financial and non-financial information". Hence, the organizations are still struggling and debating with the structure and content of the IIRF. Inadequacy of required suitable technical infrastructure and amenities causes a gap in having and applying the IIRF. Following the IIRF framework is stressful and complex for the responsible officers since it requires disclosing more information. Hence, these issues are amplified by the lack of clear directions from the IIRF [27,31].

Moreover, the organizations faced difficulties in presenting information to comply with the framework. As per interviewees noted, "Since there are specific guidelines and need to disclose on content elements, six capitals, and value creation process, the preparation of the report is sometimes a stress to us - (IN 11)', "At the first time of adoption, describing the business model was one of the most challenging parts of the report - (IN 15). Hence, describing and presenting the business model and value creation process as per the IIRF become the most complicated aspects for the firm due to the IIRF's capital nature. Even though the integrated report should consist of material information on both financial and non-financial, they face difficulties in the material determination process when they reconcile the different needs of different stakeholders. As emphasized by the interviewee IN6, "Determination of materiality is a challenge to us". Hence, the material determination becomes complex due to the difficulty of quantifying the non-financial information [49].

Furthermore, difficulties that they faced during the reporting of capital trade-off $[27,28]$ and the combination of the financial and non-financial information/integration of the information $[18,24,30,50]$ were also mentioned by the interviewees. As per interviewee IN1, "Reporting capital trade-off is a very critical thing". Therefore, reporting material trade-off between capitals or components of capital is considered as a challenge due to its complex nature. In addition, interviewee IN14 noted that "We faced difficulties when we reconciled different stakeholders' interests". The IR seeks to present stakeholders' interests, their relationships, and their contribution to the value creation process. However different stakeholders have different interests in nature, making it challenging for a firm to reconcile those interests in one report.

\subsubsection{External Factors}

The external factors that affect the adoption or enhancement of IR are discussed mainly by Steyen[4], Bananuka, et.al.,[13], Jayasiri[18], Dumay, et.al.,[31]. In line with those findings, interviewee IN1 mentioned less pressure from the stakeholders [13] as one of the main impediments on IR. According to him, "In the Sri Lankan context, the pressure from stakeholders to adopt IR is not sufficient". According to the management aspect of stakeholder theory, stakeholders can exert powers to force the organization to achieve their aspirations and management will tend to address the aspirations of more powerful stakeholders [51]. Hence, the lack of influence from stakeholders will discourage companies to move towards IR. Particularly, interviewee IN 9 highlighted that "SEC and CSE are not encouraging us". Hence, insufficient encouragement of the securities exchange commission (SEC) and Colombo stock exchange (CSE) in Sri Lanka are barriers to implementing IR. It evidenced the absence of regulatory bodies' roles, and the absence of regulatory bodies' pressures causes an institutional void. Hence, the lack of coordination among the regulatory bodies and PLCs and lack of guidance cause the lethargic adoption of IR.

Furthermore, the voluntary nature of IR was emphasized by some interviewees as a restraint to implementing reporting requirements. Hence, IR is primarily driven by other internal and external pressures than the mandatory requirements. Therefore, no mandatory requirement to adopt [31] also becomes an external barrier that Sri Lankan companies face on IR. Some interviewees emphasized this as, I think the voluntary nature is restricting the $I R$ adoption (IN 12), IR is voluntary; hence, there is no statutory requirement to follow it and adopt the practice(IN 8), If IR is set as mandatory, it affects to create pressure on the adoption, and it will enhance the $I R$ practice (IN 10). Hence, the nonmandatory nature of the IR is identified as an impediment because they experienced that the voluntary nature of the integrated reporting is also caused not to have the substantial disclosures, and it affects to diminish the quality of the report. Hence, some regulations may be necessary to enhance IR practice [52]. However, if IR is set as a compliance-driven practice, it causes difficulties [4] from adopting the firms.

\subsubsection{Organizational Factors}

The organization itself also created some barriers to implementing or enhancing IR practices of the organization, and these challenges are discussed by the prior studies Anojan[15], Jayasiri[18], Iacuzzi[24], 
Lakshan[25], Robertson \& Samy[28], Maroun \& Mcnally[29], Feng, et al. [32], Bananuka, et.al.,[53].In line with those studies, this study also found that the lack of a proper information system $[18,25]$ is as impediments. " $A t$ the first year of adoption, it was challenging to gather the required information and initially, we have resistance from the employees to provide information" (IN 2). Hence, organizations are struggling with the data collection and validation of those data. In addition to that, the lack of data repository system also may be an impediment. Furthermore, employees' resistance to change [18, 25], the difficulty of convincing the benefits from IR to stakeholders, more time-consuming [18,24], are identified as impediments to IR by interviewees. The first challenge is to convince all the stakeholders of the benefits of IR... It is a time-consuming exercise, and with day-to-day engagements, it is not something that can be done without additional commitment...It is not something widely complied hence the expertise in the whole process is limited and costly-IN4"," At the initial stage, employees believed IR as the additional burden - IN 10". Although all decisions, including IR, come from senior management, such managers have an inadequate understanding of the importance and benefits of IR in the decision-making process adversely affects IR training. It increases management stress on the implementation of IR. Therefore, not recognizing the value of IR and believing it as an additional burden forced reluctance to engage with IR [38]. Hence, at the beginning of the implementation, the commitment by employees was challenging to gauge. The resistance to change may occur due to the fear of the creep of their job scope and additional time commitment. Furthermore, capturing relevant information and matching them with the framework may be extremely costly to the organizations. Moreover, interviewee IN8 emphasized that "handling the different perspectives of officers of the integrated report preparation process is also a challenge for us". Different officers from different departments are involved with the integrated reporting process. Hence, their different perspectives are considered a challenge [39] for assimilating the integrated report.

Moreover, as some interviewees highlighted, the lack of expertise $[13,18,25]$ for the entire IR process and lack of knowledge are also mentioned as impediments to implementing IR practices in Sri Lankan companies. "The novelty of the concept and lack of knowledge on the framework was another challenge for an organization deciding to follow" (IN4), employees' knowledge and experiences were insufficient at the time we introduced IR (IN 10). These statements are evidence that little expertise and knowledge would be a challenge to introduce a new corporate reporting model to the organization $[38,39]$. Hence, as the concept of IR is relatively new to companies, organizations are less aware, less experienced, and less knowledgeable about it. Hence, management faced difficulties in directing staff to initiate IR implementation.

\subsection{Integrated Reporting and Organizational Sustainability}

IR can be identified as the one step forward in sustainability reporting (SR). It extends SR [36,40,41]. Furthermore, IR is the latest development of SR, and the annual report, combined with the information of sustainability report, can be identified as the early stage of IR [41,54]. In line with those conclusions, Sri Lankan companies also show that they move to IR as the subsequent reporting of sustainability reporting and how they used SR information at their early stage of IR. This may be because parts of IR disclosures are already included in the sustainability reports [36], and IR combines the facets of SR [55]. The interviewees emphasized that," In 2010, we were the leading from sustainability reporting, and then we discussed what should be our next reporting. Actually, at the time we started IR, there was no format; hence what we did was use sustainability reporting data for our first integrated report - IN 1", "Sustainability reporting is a different one, but the same information can be used to IR - IN 5", "We believe IR as the next generation of $S R-I N$ 8", "Before adopting $I R$, we have used SR. Hence, we were keen and practiced reporting or, in other words, preparing the annual report as per the framework. It was beneficial to us move to IR, and we were able to use the same template by adding additional information as per IIRF - IN 3". Hence, even though some elements of SR and IR conflict, the organizations tend to follow most of the disclosures of SR in their integrated reports. Therefore, a robust SR process is the base for organizations' IR processes [6].

Integrated thinking is directly linked to sustainability [56] and achievement of sustainable development goals requires the practice of integrated thinking [1]. Adoption of IR will cause to practice integrated thinking and it will assist in successfully integrating sustainability into the business model [56]. The interviewers evidenced gradual improvement of senior management commitment on sustainability issues after adopting IR practices [44]. "Actually, our senior management focus on organizational sustainability is increased after the adoption of IR - IN 4". Indeed, the sustainable development goals can be achieved through the corporation and commitment of different actors. Hence, the adoption of IR practice will enhance the integrated thinking practice and it will ultimately cause the enhancement of organizational sustainability.

In addition, IR assists in integrating sustainability issues into organizations' strategies [42]. Furthermore, in line with the conclusions of Gelmini \& Vola, [57], the respondents believed that the IR enhances organizational sustainability. Hence, organizations take proactive actions for the environment and social issues through the sustainability committee and having stakeholder engagement practices. "We previously, just report sustainability information in our annual report, but the adoption of IR shows the way to integrate sustainability 
into the business model - IN 2", "We think that the adoption of IR enhances our sustainability practices - IN 13", "We have a sustainability committee with the main purpose of identifying the impact of sustainability issues IN 1", "We have sound stakeholder engagement practices to identify the sustainability issues, and we believe it is one of the reasons to win IR awards - IN 7". Therefore, release of IIRF causes to enhance the case of sustainable business. Hence, organizations who follow IR, disclose sustainable issues in an integrated fashion.

Organizations with a good sustainability committee and having sound stakeholder engagement practices can produce a quality integrated report by identifying and integrating sustainability issues into organizational strategies. Hence, adaptation to IR by minimizing barriers contributes to introducing and enhancing the internal use of sustainability issues while integrating sustainability issues into strategy and reflecting sustainability performance indicators. Therefore, the non-adoption of IR practices due to the impediments may hinder the organizational adaptation towards sustainability enhancement.

\section{Conclusion}

This study sought to identify the impediments to the adoption of IR practice and how adoption/ non-adoption of IR affects organizational sustainability reporting. The study used qualitative data to explore the impediments and their impacts on organizational sustainability. The study identified and discussed the impediments into three categories: technical, external, and organizational factors, thus adding more surface to the flourishing debate about the impediments of IR. Moreover, this study concluded IR as one step forward to SR. The integration of organizational sustainability issues to organizational strategies is strengthened through integrated thinking practices, enhancement of senior management commitment, sound sustainability committee, and sound stakeholder engagement practices, which are gradually inculcated into the organization with the adoption of IR. Hence, it can be concluded that the non-adoption of IR due to the impediments may affect organizational sustainability.

The results may provide the impetus for mitigating IR impediments in a developing country context towards organizational sustainability. Hence, the knowledge presented here is relevant to the firms involved in IR adoption and professional accounting bodies and regulatory bodies. Implementation impediments can be informative for them to improve IR in mandatory or voluntary nature. Individual organizations looking for ways to enhance their specific approaches to IR can also benefit from this knowledge. Therefore, effective, and successful IR practices may be achieved by minimizing the impediments identified and focusing on organizational sustainability.
The findings of this study suggest the implications and recommendations for academia and practitioners. The voluntary nature of IR may slow the adoption and progress of IR, and the findings of this study also identified the threat of stifling its adoption and enhancement by not mandating integrated reporting. Colombo Stock Exchange and Securities Exchange Commission together can take action in this regard. Therefore, after studying the integrated reporting framework, regulatory bodies can make legislation on some disclosures such as relating sustainability disclosures, integration of financial and non-financial disclosures, and risk management process, etc., which companies must disclose and can take those into account when satisfying the company listing requirements like South Africa and Brazil. Furthermore, to ensure that members of the professional accounting bodies (PABs) are updated and aware of the IR framework and its recent developments, PABs continuously conduct training and awareness programs, roundtable discussions, and forums. This action will help PLCs to understand some complicated facts of the IR framework.

In addition, this study also evidenced that the integration of sustainability information to organizational strategies is strengthened through the adoption of IR practice. Hence, organizations need to understand the organizational impediments faced in adopting IR to develop a successful IR practice. Using this knowledge, organizations can consider which impediments may occur in their organizations and the preventive actions that can be taken in this regard. They should overcome the old way of thinking in IR practice. For example, employees may feel that IR adoption is an additional burden to them. Furthermore, management stress on the critical factors of $\mathrm{R}$ adoption suggests the importance of inculcating and improving the awareness of IR practice among the responsible officers by providing opportunities to participate in the workshops, training programs, and seminars conducted by the professional accounting bodies.

However, the findings of our study have some limitations which direct to future studies. First, our research finding is based on a relatively small number of interviews in the context of a specific developing country. Hence, future studies may provide a more comprehensive understanding of the barriers to IR and the impact of IR's adoption to organizational sustainability in Sri Lanka by giving an overall assessment of response to IR through detailed case studies in the context of large samples. Second, this study's findings can be extended by comparing the impediments on IR of developed and developing countries.

\section{REFERENCES}

[1] Adams C. A., "The Sustainable Development Goals, integrated thinking and the integrated report" 
https://www.integratedreporting.org/wp-content/uploads/2 017/09/SDGs-and-the-integrated-report_full17.pdf,2017(a ccessed May 15, 2021)

[2] IIRC., "Towards integrated reporting, communicating value in the 21 st Century". http://integratedreporing.org/w pcontent/uploads/2011/09/IR-Discussion-Paper-2011_spre ds.pdf, 2011, (accessed April 3, 2021)

[3] de Villiers C., Hsiao P.C. K., \& Maroun W., "Developing a conceptual model of influences around integrated reporting, new insights and directions for future research". Meditari Accountancy Research, Vol.25, No.4, pp.450-460, 2017a. . DOI: 10.1108/MEDAR-07-2017-0183

[4] Steyn M., "Organisational benefits and implementation challenges of mandatory integrated reporting: Perspectives of senior executives at South African listed companies", Sustainability Accounting, Management and Policy Journal, Vol.5, No.4, pp.476-503, 2014. DOI: 10.1108/SAMPJ-112013-0052

[5] Vitolla F., Raimo N., \& Rubino M., "Appreciations, criticisms, determinants, and effects of integrated reporting: A systematic literature review", Corporate Social Responsibility and Environmental Management, Vol.26, No.2, pp.518-528, 2019. DOI: 10.1002/csr.1734

[6] Adams C. A., "The International Integrated Reporting Council: A call to action", Critical Perspectives on Accounting, Vol.27, pp.23-28, 2015. DOI: 10.1016/j.cpa.2014.07.001

[7] Ioana D., \& Adriana T.T., "Research Agenda on Integrated Reporting: New Emergent Theory and Practice", Procedia Economics and Finance, Vol.15, pp.221-227, 2014. DOI: $10.1016 / \mathrm{S} 2212-5671(14) 00488-2$

[8] B20, "Unlocking investment in infrastructure: Is current accounting and reporting a barrier?" http://integratedreport ing.org/wp-content/uploads/2014/06/unlocking-investment -in-infrastructure.pdf, 2014, (accessed August 20, 2021)

[9] ICASL, "Code of Best Practice on Corporate Governance", Institute of Chartered Accountants of Sri Lanka. https://www.casrilanka.com/casl/imagesstories/2017/2017 _pdfs/code_of_best_practice_on_corporate_governance_2 017_final_for_web.pdf, 2017, (accessed August 21, 2021)

[10] SEC, "Capital Market Strategy 2020", Securities and Exchange Commission of Sri Lanka. http://www.sec.gov.l k/wp-content/uploads/Capital-Market-Strategy-2020-pdf.p df, 2016, 2020, (accessed May 30, 2021)

[11] Pathiraja P. M. D. S., \& Priyadarshanie W.D.N., "Integrated Reporting Disclosures: An Empirical Analysis", International Research Conference of UWU, 2019.

[12] Abeysinghe C., "An Assessment of Integrated Performance Reporting: Three Case Studies In Sri Lanka", Journal of the Institute of Chartered Accountants of Sri Lanka, pp.1-25, 2020 .

[13] Bananuka J., Tumwebaze Z., \& Orobia L. A., "The adoption of integrated reporting: A developing country perspective", Journal of Financial Reporting and Accounting, Vol.17, No.1, pp.2-23, 2019. DOI: 10.1108/JFRA-09-2017-0089

[14] La Torre M., Bernardi C, Guthrie C, \& Dumay J, "Integrated reporting and integrated thinking: Practical challenges", In Arvidsson (Ed.), Challenges in Managing Sustainable Business, 2019.

[15] Anojan V., "Perception of Accounting Experts on the Implementation of Integrated Reporting in Sri Lanka", Global Journal of Management and Business Research: D Accounting and Auditing, Vol.19, No.1, pp.62-68, 2019.

[16] Gunarathne A. D. N, \& Senaratne, S, “Country Readiness in Adopting Integrated Reporting: A Diamond Theory Approach from an Asian Pacific Economy", In K.-H. Lee \& S. Schaltegger (Eds.), Accounting for Sustainability: Asia Pacific Perspectives, Vol. 33, pp. 39-66, Springer International Publishing, 2018.DOI:10.1007/978-3-319-70 899-7_3

[17] Gunarathne N., \& Senaratne S., "Diffusion of integrated reporting in an emerging South Asian (SAARC) nation", Managerial Auditing Journal, Vol. 32, no.4/5, pp/524-548, 2017. DOI: 10.1108/MAJ-01-2016-1309

[18] Jayasiri N. K., "Integrated Reporting in Sri Lanka: An Exploratory Study", [PhD Thesis]. University of Otago, 2020.

[19] Kılıç M., \& Kuzey C., "Assessing current company reports according to the IIRC integrated reporting framework", Meditari Accountancy Research, Vol.26, no.2, pp/305-333, 2018. DOI: 10.1108/MEDAR-04-2017-0138

[20] Al-Htaybat K., \& von Alberti-Alhtaybat L., "Integrated thinking leading to integrated reporting: Case study insights from a global player", Accounting, Auditing \& Accountability Journal, Vol.31, No.5, pp.1435-1460, 2018. DOI: 10.1108/AAAJ-08-2016-2680

[21] Silvestri A, \& Veltri S, "Integrated Report: Is it a Strong or Weak Accountability Tool?", In S. O. Idowu \& M. Del Baldo (Eds.), Integrated Reporting, pp. 169-183, Springer International Publishing, 2019. DOI: 10.1007/978-3-030-0 1719-4_9

[22] IIRC., "The International Integrated Reporting Framework" http://www.theiirc.org/wp-content/uploads/2013/12/12-12. 08.THE-INTERNATIONAL-IR-FRAMEWORK-2-1-pdf, 2013, (accessed May.21, 2021).

[23] IIRC., "International <IR $>$ Framework", https://integratedr eporting.org/wpcontent/uploads/2021/01/InternationalInte gratedReportingFramework.pdf, 2021, (accessed August 5, 2021)

[24] Iacuzzi S., Garlatti A., Fedele P., \& Lombrano A., "Integrated reporting and change: Evidence from public universities", Journal of Public Budgeting, Accounting \& Financial Management, vol.32, no.2, pp.291-310, 2020. DOI: 10.1108/JPBAFM-08-2019-0120

[25] Lakshan A. M. I., "Integrated Reporting in Sri Lankan PLCs", PhD thesis, University of Waikato, 2018.

[26] Lodhia S., "Exploring the Transition to Integrated Reporting Through a Practice Lens: An Australian Customer Owned Bank Perspective", Journal of Business Ethics, vol.129, no.3, pp.585-598. 2015. DOI:10.1007/s10 551-014-2194-8

[27] Cheng M., Green W., Conradie P., Konishi N., \& Romi A., "The International Integrated Reporting Framework: Key Issues and Future Research Opportunities", Journal of International Financial Management \& Accounting, vol.25, 
no.1, pp.90-119, 2014. DOI:10.1111/jifm.12015

[28] Robertson F. A., \& Samy M., "Factors affecting the diffusion of integrated reporting - a UK FTSE 100 perspective", Sustainability Accounting, Management and Policy Journal, vol.6, no.2, pp.190-223, 2015. DOI: 10.1108/SAMPJ-07-2014-0044

[29] Maroun W., \& Mcnally M. A., "Is not always bad news: Illustrating the potential of integrated reporting using a case study in the eco-tourism industry, Accounting, Auditing \& Accountability Journal, vol.31, no.5, pp.1319-1348, 2018. DOI: 10.1108/AAAJ-05-2016-2577

[30] PwC., "Integrated reporting where to next?", https://www.pwc.co.za/en/assets/pdf/integrated-reporting-s urvey-2015.pdf, 2015, , (accessed August 15, 2021).

[31] Dumay J., Bernardi C., Guthrie J., \& La Torre M., "Barriers to implementing the International Integrated Reporting Framework: A contemporary academic perspective", Meditari Accountancy Research, vol.25, no.4, pp.461-480, 2017. DOI: 10.1108/MEDAR-05-2017-0150

[32] Feng T., Cummings L., \& Tweedie D., "Exploring integrated thinking in integrated reporting - an exploratory study in Australia", Journal of Intellectual Capital, vol.18, no.2, pp.330-353, 2017. DOI: 10.1108/JIC-06-2016-0068

[33] Hahn T., Preuss L., Pinkse J., \& Figge F.," Cognitive Frames in Corporate Sustainability: Managerial Sensemaking with Paradoxical and Business Case Frames", Academy of Management Review, vol.39, no.4, pp.463487, 2014. DOI: $10.5465 / \mathrm{amr} .2012 .0341$

[34] Ara M. \& Harani B., "Integrated Reporting Insight: Why Organisation Voluntarily Reports?", International Journal of Scientific and Technology Research, vol,9, no.01, pp.3055-3069, 2020.

[35] Camilleri M. A, "Theoretical Insights on Integrated Reporting: Valuing the Financial, Social and Sustainability Disclosures", In S. O. Idowu \& M. Del Baldo (Eds.), Integrated Reporting, pp. 61-76, Springer International Publishing, 2019. DOI: 10.1007/978-3-030-01719-4_3

[36] Mauro S. G., Cinquini L., Simonini E., \& Tenucci A., "Moving from Social and Sustainability Reporting to Integrated Reporting: Exploring the Potential of Italian Public-Funded Universities' Reports", Sustainability, vol.12, no.8, pp.1-19, 2020. DOI: 10.3390/su12083172

[37] Oktorina M., Siregar,S. V., Adhariani D., \& Mita A. F., "The diffusion and adoption of integrated reporting: A cross-country analysis on the determinant", Meditari Accountancy Research, ahead-of-print, 2021. DOI: 10.1108/MEDAR-12-2019-0660

[38] Perego P., Kennedy S., \& Whiteman G., "A lot of icing but little cake? Taking integrated reporting forward", Journal of Cleaner Production, Vol.136, no.53-64, 2016. DOI: 10.1016/j.jclepro.2016.01.106

[39] Adams C. A., \& McNicholas P., "Making a difference: Sustainability reporting, accountability and organisational change", Accounting, Auditing \& Accountability Journal, vol.20, no.3, pp.382-402, 2007. DOI: 10.1108/095135707 10748553

[40] de Villiers C., Venter E. R., \& Hsiao P.C. K., "Integrated reporting: Background, measurement issues, approaches and an agenda for future research.”, Accounting \& Finance, vol.57, no.4, pp.937-959, 2017b. DOI: 10.1111/acfi.12246

[41] Stubbs W., \& Higgins C., "Integrated Reporting and internal mechanisms of change.", Accounting, Auditing \& Accountability Journal, vol.27, no.7, pp.1068-1089, 2014. DOI: 10.1108/AAAJ-03-2013-1279

[42] Băndoi A., Bocean C. G., Del Baldo M., Mandache L., Mănescu L. G., \& Sitnikov C. S., "Including Sustainable Reporting Practices in Corporate Management Reports: Assessing the Impact of Transparency on Economic Performance", Sustainability, vol.13, no.2, pp.1-20, 2021. DOI: $10.3390 / \mathrm{su} 13020940$

[43] IIRC., "Understanding transformation: Building the business case for integrated reporting", http://integratedrep orting.org/wpcontent/uploads/2012/11/BUILDING-THEBUSINESS-CASE-FORINTEGRATED-REPORTING.pd f. 2021. (accessed April 29, 2021)

[44] Churet C., \& Eccles R. G., "Integrated Reporting, Quality of Management, and Financial Performance", Journal of Applied Corporate Finance, vol.26, no.1, pp.8-16, 2014.

[45] Atkins J., \& Maroun W., "Integrated reporting in South Africa in 2012: Perspectives from South African institutional investors", Meditari Accountancy Research, vol.23, no.2, pp.197-221, 2015. DOI; 10.1108/MEDAR-0 7-2014-0047

[46] Doni F., Larsen M., Bianchi Martini S., \& Corvino A., "Exploring integrated reporting in the banking industry: The multiple capitals approach", Journal of Intellectual Capital, 2019. DOI: 10.1108/JIC-11-2017-0146

[47] Azam S. M. F., Yajid M. S., Tham J., Hamid, J. A., Khatibi A., Johar M. G. M. \& Ariffin I. A. . Research Methodology: Building Research Skills. $1^{\text {st }}$ Ed., McGraw-Hill Education (Malaysia) Sdn. Bhd. 2021

[48] Bailey B. C., \& Peck S. I., "Boardroom Strategic Decision-Making Style: Understanding the Antecedents: The antecedents for boardroom decision making", Corporate Governance: An International Review, vol.21, no.2, pp.131-146, 2013 .DOI: 10.1111/corg.12008

[49] Lakshan A. M. I., Low M., \& de Villiers C., "Challenges of, and techniques for, materiality determination of non-financial information used by integrated report preparers", Meditari Accountancy Research, ahead-of-print, 2021. DOI: 10.1108/MEDAR-11-2020-1107

[50] Favato K. J., Neumann M., Sanches S. L. R., Branco M. C., \& Nogueira D. R., "Integrated Thinking and Reporting Process: Sensemaking of Internal Actors in the Case of Itaú Unibanco", Journal of Risk and Financial Management, vol.14, no.6, pp.1-16, 2021. DOI: 10.3390/jrfm14060245

[51] Gray R., Owen D. and Adams C., "Accounting and Accountability: Changes and Challenges in Corporate Social and Environmental Reporting", Prentice-Hall, London, 1996.

[52] Stubbs W., \& Higgins C., "Stakeholders' Perspectives on the Role of Regulatory Reform in Integrated Reporting", Journal of Business Ethics, vol.147, no.3, pp.489-508, 2018. DOI: $10.1007 / \mathrm{s} 10551-015-2954-0$

[53] Bananuka J., Night S., Ngoma M., \& Najjemba, G. M., 
"Internet financial reporting adoption: Exploring the influence of board role performance and isomorphic forces." Journal of Economics, Finance and Administrative Science, vol.24, pp.266-287., 2019a. DOI: 10.1108/JEFAS-11-201 $8-0120$

[54] Camodeca R., \& Almici A., "Implementing Integrated Reporting: Case Studies from the Italian Listed Companies", Accounting and Finance Research, vol.6, no.2, pp.121-135, 2017. DOI: 10.5430/afr.v6n2p121

[55] Wachira M. M., Berndt T., \& Romero C. M., "The adoption of international sustainability and integrated reporting guidelines within a mandatory reporting framework:
Lessons from South Africa", Social Responsibility Journal, vol.16, no.5, pp.613-629, 2019. DOI: 10.1108/SRJ-12-201 8-0322

[56] Oliver J., Vesty G., \& Brooks A., "Conceptualising integrated thinking in practice", Managerial Auditing Journal, vol.31, no.2, pp.228-248, 2016. DOI: 10.1108/MAJ-10-2015-1253

[57] Gelmini L., \& Vola P., "Integrated reporting and environmental disclosure: Is natural capital neglected?", Corporate Ownership and Control, vol.18, no.2, pp.131139, 2021. DOI: $10.22495 / \operatorname{cocv} 18 i 2$ art 